\title{
COVID-19: Meningkatkan Kesadaran Hidup Bersih dan Aktivitas Fisik dalam Mendukung Kuliah Daring
}

Oleh: Susanto, M.Or ${ }^{1}$

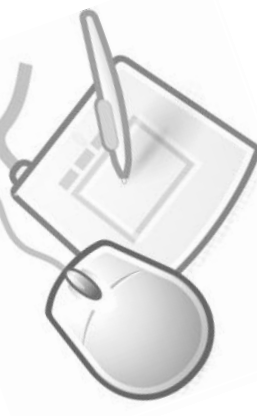

"Dalam upaya mendukung perkuliahan daring, tidak hanya teknologi informasi saja yang berperan, namun ada dukungan lain yaitu dengan menjaga kebugaran fisikjuga tidak kalah pentin,"

B erawal munculnya kasus corona pada awal tahun 2020 tepatnya di kota wuhan cina, membuat hampir setiap negara berupaya keras dalam menghambat penyebaran virus covid-19, dengan berbagai cara salah satunya membatasi keluar masuk manusia dan dilakukannya tindakan karantina bagi daerah yang sudah pandemi.

Namun selang beberapa bulan saja penyebaran virus sudah merambah keratusan negara di dunia termasuk indonesia. Indonesia sendiri saat ini sudah memberlakukan social distancing dan physical distancing, sebagai usaha usaha dalam menghambat penyebaran covid-19 yang sangat cepat sekali. Terkait dengan upaya mengahambat penyebaran covid-

\footnotetext{
${ }^{1}$ Lulusan Pendidikan Kesehatan Rekreasi FIK Universitas Negeri Yogyakarta melalui jalur PMDK/PBU. Pernah bekerja di FIK Universitas Negeri Yogyakarta pada 2009, pernah menjadi Dosen tamu di Universitas Bina Darma (UBD) Palembang, pernah bekerja sebagai Dosen di Universitas Muhammadiyah Sukabumi (UMMI) Jawa Barat tahun 2013, dan saat ini bekerja sebagai Dosen di Institut Agama Islam Negeri Tulungagung sampai sekarang.
} 
19tersebut, dapat behasil jika semua lapisan masyarakat dapat memahami dan mendukung sosial distancing dan physical distancing. Selain ituada berbagai upaya lain yang dapat mahasiswa lakukan untuk menghambat penyebaran covid-19.

Perlunya kesadaran akan kebersihan diri perlu di tingkatkan lagi, seperti rajin mencuci tangan setiap kali selesai beraktivitas atau setelah melakukan perjalanan. Mahasiswa sebagai masyarakat akademis semenjak merebaknya kasus covid-19, meningkatnya kesadaran akan menjaga kebersihan diri, lingkungan dan menjaga kondisi fisik.

Hal tersebut penting dilaksanakan mengingat mahasiswa melakukan interaksi yang sangat intensif dengan mahasiswa lain dan masyarakat sekitarnya. disisi lain sebagai seorang mahasiswa berkewajiban memberikan edukasi dan sebagai contoh terkait pentingnya menjaga kebersihan demi terwujudnya masyarakat yang sehat.

Mengutip dari sebuah hadist yang sudah familiar di telinga kita yang diriwayatkan oleh Ahmad, "Kebersihan itu sebagian dari iman." Kebersihan bersumber dari iman dan merupakan bagian dari iman. Dengan demikian, kebersihan dalam Islam mempunyai aspek ibadah dan aspek moral. Lalu pertanyaan apa yang dimaksud dengan kebersihan itu sendiri adalah segala upaya atau usaha manusia dalam menjaga diri dan lingkungannya dari segala yang kotor untuk mewujudkan dan melestarikan kehidupan yang sehat dan nyaman.

Kebersihan adalah syarat untuk mewujudkanya kesehatan. Sementara menjadi sehat adalah salah satu faktor yang bisa memberikan kebahagiaan. Sebaliknya, kotor tidak hanya merusak keindahan namun juga dapat menyebabkan timbulnya berbagai jenis penyakit, sementara penyakit ialah salah satu faktor yang menyebabkan penderitaan bagi manusia. 
Meningkatkan kesadaran kebersihan lingkungan. Kebersihan lingkungan adalah menciptakan sebuah lingkungan sehat sehingga lingkungan tesebut tidak mudah terserang oleh berbagai jenis penyakit seperti malaria, demam berdarah, muntaber, kaki gajah dan penyakit lainnya.

Dengan demikian selain menjaga kebersihan diri, penting juga dalam menjaga lingkungam sekitarnya. Sebagai mahasiswa, dimana sebagian besar tinggal di pemondokan kerapkali sentimen negatif ditujukan pada anak kos yang dianggap masyarakat kurang dalam hal menjaga kebersihan sebagai contoh membuang sampah tidak pada tempatnya, parkir motor sembarangan.

Meningkatkan Sistem imun atau sistem kekebalan adalah selsel yang ada pada tubuh manusia dan banyak struktur biologis lainnya yang bertanggung jawab atas imunitas, yaitu pertahanan pada organisme untuk melindungi tubuh dari berbagai pengaruh biologis luar dengan mengenali dan membunuh patogen.

Imunitas sebagai benteng pertahanan tubuh dalam memerangi berbagai virus, perlu mendapat perhatian oleh para mahasiswa. upaya tersebut bisa dilakukan dengan cara antaralian mengelola stres, istirahat yang cukup, asupan gizi yang seimbang dan mengonsumsi vitamin terutama vitamin $\mathrm{C}$ dan vitamin E serta memperbanyak asupan makanan dengan anti oksidan tinggi.

Melakukan hidup aktif seperti berolahraga secara teratur. Selain asupan gizi dan menambah asupan vitamin, tidak kalah pentingnya dengan menjaga kebugaran tubuh. semakin tingginya kebugaran tubuh seseorang maka daya imunitas semakin kuat. hal tersebut terjadi karena produksi hormon endorfin yang meningkat pada saat berolahraga dapat mempengaruhi produksi hormon imun. 


\section{늘 Kuliah Daring}

Olahraga juga telah terbukti mampu dalam meningkatkan daya tahan tubuh dan meredakan peradangan. Tetapi perlu diingat, olahraga yang dilakukan secara teratur memiliki efek yang lebih baik terhadap sistem imun ketimbang olahraga yang hanya dilakukan sesekali. Jadi, sempatkan dan luangkan waktu untuk berolahraga sedikitnya 30 menit setiap hari atau 150 menit dalam seminggu minimal 3-4 kali dalam seminggu dengan intensitas sedang, hal ini juga sesuai dengan anjuran WHO terkait pedoman aktivitas fisik bagi orang dewasa dan 75 menit melakukan aktivitas fisik dengan intensitas berat dalam seminggunya.

Sebagai contoh program perencanaan dengan intensitas sedang untuk orang dewasa dengan indikator MET masih menghirup banyak oksigen, dan jenis kegiatannya seperti Joging, bersepeda, renang dll. Bagi yang sudah terbiasa melakukan aktivitas fisik intensitas sedang, bisa dilanjutkan dengan aktivitas fisik intesitas berat, indikatornya sedikit menggunakan oksigen, jenis kegiatannya seperti; lari cepat, sepak bola, futsal dll.

Dampak yang dirasakan pada dunia pendidikan adalah pembatasan interaksi perkuliahan secara tatap muka beralih ke perkuliahan jarak jauh seperti dengan melakukan kuliah daring. Perkuliahan yang memanfaatkan teknologi informasi bagi sebagian mahasiswa terlihat masih canggung, namun dengan adanya kasus wabah covid-19 interaksi tatap muka ditiadakan maka salah satu upaya agar perkuliahan tetap berlangsung mahasiswa dituntut untuk belajar secara cepat dalam menguasai teknologi informasi.

Terkendalanya jaringan menjadi hambatan oleh sebagian mahasiswa yang tinggal di wilayah pedesaan, hal tersebut terkadang mengganggu koneksi jaringan internet ketika 
melakukan perkulihana daring. Namun terkendalanya jaringan dapat diselesaikan dengan cara mahasiswa bisa memilih provider dengan jaringan internet paling kuat didaerahnya.

Dalam upaya mendukung perkuliahan daring, tidak hanya teknologi informasi saja yang berperan, namun ada dukungan lain yaitu dengan menjaga kebugaran fisik juga tidak kalah penting. Dengan menjaga kebugaran fisik seorang mahasiswa nantinya tidak mudah lelah dalam melaksanakan aktivitas perkuliahan daring.

Mengingat kuliah daring dengan aktivitas duduk dalam jangka waktu lama membuat mahasiswa kelelahan secara fisik. Oleh karenanya perlunya kesadaran mahasiswa dalam menjaga stamina kebugaran fisiknya agar kegiatan kuliah daring tidak terhambat.

Seperti kita ketahui dalam berbagai survey yang telah dilakukan ternyata masyarakat kita termasuk paling rendah dalam melakukan aktivitas fisik seperti jalan kaki dibanding negaralain seperti jepang yang paling tinggi penduduknya melakukan aktivitas jalan kaki.

Dengan demikian, berbagai usahayang dapat dilakukan oleh mahasiswa dalam pencegahan dan membatasi penularan covid19 perlu ditingkat. Seperti tidak melakukan kegiatan berkumpul dan melakukan perjalanan yang dirasa tidak mendesak.

Sebagai masyarakat akademis mahasiswa sebagai agen perubahan dan generasi penerus bangsa perlu ikut andil dalam mendukung setiap upaya pemerintah dalam penanganan virus covid-19, agar negara kita segara cepat dalam pemulihan dari wabah tersebut.

Hal ini penting untuk didukung mengingat dampak wabah virus covid-19 sangat berdampak sekali dari berbagai sektor 
ver Kuliah Daring

bidang seperti bidang kesehatan, ekonomi, pendidikan dan politik. 